Jacek Batóg*

Uniwersytet Szczeciński

Magdalena Mojsiewicz $^{* *}$

Uniwersytet Szczeciński

Barbara Batóg***

Uniwersytet Szczeciński

\title{
MONITOROWANIE STRATEGII ROZWOJU W ŚWIETLE DELIMITACJI MIEJSKICH OBSZARÓW FUNKCJONALNYCH
}

\section{Streszczenie}

Obszary metropolitalne w Polsce zaczynają dopiero tworzyć strategie rozwoju, a w ich ramach systemy monitorowania i oceny realizacji celów strategicznych oraz szczegółowych. Występuje silne zróżnicowanie kształtu tych dokumentów i procedur. Przegląd istniejących krajowych strategii rozwoju i systemów monitorowania miejskich obszarów funkcjonalnych oraz rozwiązań stosowanych w tym zakresie na świecie wskazuje na konieczność opracowania odpowiedniej informacji statystycznej. Warto opracować zbiór wskaźników charakteryzujących stan i zmiany zjawisk zachodzących na obszarach metropolitalnych, który pozwoliłby porównywać te obszary w skali krajowej i międzynarodowej. W artykule dokonano analizy zmiany sytuacji gospodarczej polskich obszarów metropolitalnych w roku 2013 w stosunku

* Adres e-mail: batog@wneiz.pl.

** Adres e-mail: mojsiv@wneiz.pl.

*** Adres e-mail: barbara.batog@wneiz.pl. 
do roku 2010. Zauważono zgodność uzyskanych rankingów tych obszarów z rankingami województw, w których one występują, oraz wysoką stabilność otrzymanych rankingów.

Słowa kluczowe: obszary funkcjonalne, obszary metropolitalne, monitoring

\section{Wprowadzenie}

Według oceny ONZ w 2014 roku 54\% populacji światowej stanowiły osoby zamieszkujące na terenach miejskich, a wskaźnik urbanizacji w 2050 roku będzie się kształtował na poziomie 66\%. Najbardziej zurbanizowanym kontynentem jest obecnie Ameryka Północna (82\% ludności stanowi ludność miejska). Wysoki odsetek ludności miejskiej charakteryzuje również Amerykę Południową i Środkową (80\%) oraz Europę $73 \%$.

Zachodzące procesy urbanizacyjne powodują sytuację, w której większość nowych wyzwań dotyczących zrównoważonego rozwoju będzie pojawiać się właśnie na terenach miejskich i sąsiadujących z nimi. W wielu krajach wprowadza się instrumenty polityk zintegrowanych na rzecz poprawy warunków życia ludności w tych obszarach, co powoduje konieczność precyzyjnego ich zdefiniowania. Stosowana w tym zakresie terminologia jest stosunkowo różnorodna. Podstawowe znaczenie mają tu definicje aglomeracji miejskiej i miejskiego obszaru funkcjonalnego.

Aglomeracja miejska to obszar, który cechuje wysoki stopień zagospodarowania i silna koncentracja kluczowych działalności. Jego powstanie jest przede wszystkim wynikiem koncentracji i rozwoju zabudowy oraz występowania wielu funkcji na terenie znacznie wykraczającym poza granice administracyjne jednostek go tworzących. Duże miasta i ich otoczenie są nie tylko miejscami generującymi wysoki poziom życia i zagospodarowania przestrzeni, lecz także traktowane są jako centra zmian, oddziałujące na całe regiony (Strategia rozwoju aglomeracji... 2014, s. 8).

Według Koncepcji Przestrzennego Zagospodarowania Kraju 2030 przez obszar funkcjonalny rozumiany jest wyodrębniony przestrzennie obszar, charakteryzujący się wspólnymi uwarunkowaniami geograficznymi, przestrzennymi, społeczno-gospodarczymi, systemem powiązań funkcjonalnych oraz określonymi na ich podstawie jednolitymi celami rozwoju, zapewniającymi efektywne wykorzystanie jego przestrzeni ${ }^{1}$. Natomiast miejski obszar funkcjonalny (MOF) jest to „układ osadniczy

1 W Krajowej strategii rozwoju regionalnego 2010-2020 występuje jeszcze inny rodzaj obszaru funkcjonalnego określany mianem funkcjonalnego obszaru ośrodka wojewódzkiego (FOOW), którym 
ciągły przestrzennie, złożony z odrębnych administracyjnie jednostek (gmin miejskich, wiejskich i miejsko-wiejskich) i składający się ze zwartego obszaru miejskiego oraz powiązanej z nim funkcjonalnie strefy zurbanizowanej”. Koncepcja 2030 wyróżnia cztery podtypy MOF: obszary funkcjonalne ośrodków wojewódzkich, regionalnych, subregionalnych i lokalnych. Typologia ta odnosi się do funkcji ośrodków miejskich w systemie osadniczym kraju i oparta jest głównie na ich wielkości. Miejski obszar funkcjonalny ośrodka wojewódzkiego zdefiniowano nieco odmiennie w opracowaniu Kryteria delimitacji miejskich obszarów funkcjonalnych ośrodków wojewódzkich (2013, s. 7). Jest on tam rozumiany jako „spójna pod względem przestrzennym strefa oddziaływania miasta, charakteryzująca się istnieniem powiązań funkcjonalnych oraz zaawansowaniem procesów urbanizacyjnych, wyróżniająca się z otoczenia i upodabniająca się pod pewnymi względami do głównego miasta".

Delimitację miejskich obszarów funkcjonalnych przeprowadzono zgodnie z następującymi zasadami: administracyjne, topologiczne i spełnienia liczby minimalnych kryteriów. Natomiast projekt rozporządzenia Ministra Infrastruktury i Rozwoju z 18 listopada 2014 r. w sprawie szczegółowych warunków określania obszarów funkcjonalnych i ich granic określa szczegółowo warunki, które muszą spełniać jednostki administracyjne mające tworzyć MOF ośrodka wojewódzkiego.

Nowe regulacje prawne, wprowadzone na podstawie przepisów ustawy z 24 stycznia 2014 r. o zmianie ustawy o zasadach prowadzenia polityki rozwoju oraz niektórych innych ustaw, obowiązujące od 8 kwietnia 2014 r., zamiast „obszaru metropolitalnego" definiują „miejski obszar funkcjonalny ośrodka wojewódzkiego” (MOF OW), którego granice i zasady zagospodarowania mają być określone w planie zagospodarowania przestrzennego województwa ${ }^{2}$. Często wskazuje się jednak na to, że obecnie w Polsce nie występuje jednolita i zintegrowana polityka miejska, realizowana na poziomie centralnym i samorządowym (szerzej zob. Strategia rozwoju aglomeracji... 2014, s. 11). Stwarza to określone bariery w skutecznym prowadzeniu polityki wobec MOF ośrodków wojewódzkich, która powinna przeciwdziałać nierównościom w poziomie ich zagospodarowania, pozwalać na trafniejsze definiowanie ich możliwości rozwojowych oraz na kompleksowe rozwiązywanie

jest zwarty obszar powiatów sąsiadujących z ośrodkiem wojewódzkim, o gęstości zaludnienia powyżej 150 osób $/ \mathrm{km}^{2}$.

2 Zbliżoną formą w państwach europejskich są obszary metropolitalne, zlokalizowane wokół ośrodków rdzeniowych - metropolii, których rozwój podlega stałemu monitoringowi procesów przestrzennych, gospodarczych i klimatycznych zgodnie z jednolitymi standardami. 
konfliktów występujących na ich terenie. Skuteczna realizacja polityki mającej na celu rozwój MOF i to zarówno tej skierowanej z zewnątrz, jak i tej realizowanej samodzielnie przez te obszary wymaga stworzenia ich strategii rozwoju. Strategia ta, określając m.in. docelowy obraz obszaru i cele strategiczne, pozwala ustalić, które wyzwania rozwojowe są najważniejsze dla danego obszaru.

Podstawowe cele artykułu to identyfikacja, które polskie miejskie obszary funkcjonalne, aktualnie najczęściej określane mianem obszarów metropolitalnych lub aglomeracji, mają opracowaną strategię rozwoju, a w jej ramach system monitorowania, charakterystyka istniejących systemów monitorowania, zwłaszcza pod kątem wykorzystywanych wskaźników, oraz analiza porównawcza sytuacji gospodarczej MOF w latach 2010 i 2013.

\section{Aktualny stan w zakresie strategii rozwoju i systemów monitorowa- nia MOF w Polsce}

W celu realizacji zarówno polityki prowadzonej w stosunku do istniejących miejskich obszarów funkcjonalnych, jak i własnej polityki tych obszarów ważne jest nie tylko ich uwzględnienie w wojewódzkich planach zagospodarowania przestrzennego, lecz również dysponowanie przez nie strategią rozwoju. Aktualnie na $17 \mathrm{MOF}^{3}$ strategię rozwoju opracowało jedynie siedem obszarów metropolitalnych. Dokument tego typu przygotowano też dla trzech strategii rozwoju zintegrowanych inwestycji terytorialnych (ZIT) miejskich obszarów funkcjonalnych, a w jednym przypadku strategia MOF stanowi element strategii rozwoju województwa. Oznacza to, że $6(35 \%)$ miejskich obszarów funkcjonalnych nie ma żadnej sformalizowanej strategii rozwoju (zob. tabela 1). Jeszcze gorsza sytuacja występuje w odniesieniu do systemów monitoringu, które powinny stanowić część składową systemu zarządzania strategiami rozwoju. Monitoring to działania polegające na systematycznym gromadzeniu i przetwarzaniu na potrzeby zarządzania strategią rozwoju informacji w zakresie rzeczowo-finansowego wykonania projektów oraz stopnia realizacji celów strategicznych. Celem monitorowania realizacji strategii jest ocena osiągniętych rezultatów, postępu we wdrażaniu postulowanych założeń, identyfikacja opóźnień lub nieprawidłowości w realizacji projektów oraz, na podstawie zdiagnozowanych

3 Miejskie obszary funkcjonalne Torunia i Bydgoszczy traktowane są jako wspólny obszar pod nazwą Bydgosko-Toruński Obszar Metropolitalny. 
wniosków, rekomendowanie ewentualnych zmian strategii czy działań naprawczych (Strategia rozwoju aglomeracji... 2014, s. 71) ${ }^{4}$.

Tabela 1. Strategie rozwoju i systemy monitoringu MOF w Polsce (stan na maj 2015)

\begin{tabular}{|c|c|c|c|}
\hline Miasto & Nazwa obszaru & Strategia & System monitoringu \\
\hline 1 & 2 & 3 & 4 \\
\hline Białystok & $\begin{array}{l}\text { Białostocki Obszar Metro- } \\
\text { politalny }\end{array}$ & $\begin{array}{l}\text { dla ZIT Białostockiego Ob- } \\
\text { szaru Funkcjonalnego }\end{array}$ & $\begin{array}{l}\text { dla ZIT Białostockiego } \\
\text { Obszaru Funkcjonalnego } \\
\text { (szeroki zestaw wskaź- } \\
\text { ników ogólnych oraz } \\
\text { wskaźników produktu } \\
\text { i rezultatu) }\end{array}$ \\
\hline $\begin{array}{l}\text { Bydgoszcz- } \\
\text {-Toruń }\end{array}$ & $\begin{array}{l}\text { Bydgosko-Toruński Obszar } \\
\text { Metropolitalny }\end{array}$ & brak & brak \\
\hline Gdańsk & $\begin{array}{l}\text { Obszar Metropolitalny } \\
\text { Gdańsk-Gdynia-Sopot }\end{array}$ & \begin{tabular}{|l|} 
dla ZIT Obszaru Metropoli- \\
talnego Zatoki Gdańskiej
\end{tabular} & brak \\
\hline Gorzów Wlkp. & $\begin{array}{l}\text { Miejski Obszar Funkcjo- } \\
\text { nalny Gorzowa Wielko- } \\
\text { polskiego (Aglomeracja } \\
\text { Gorzowska) }\end{array}$ & brak & brak \\
\hline Katowice & Metropolia „Silesia” & opracowana & $\begin{array}{l}\text { tylko ogólny opis zakresu } \\
\text { i zasad monitoringu }\end{array}$ \\
\hline Kielce & $\begin{array}{l}\text { Kielecki Obszar Metro- } \\
\text { politalny }\end{array}$ & brak & $\begin{array}{l}\text { brak (ogólny opis w pro- } \\
\text { jekcie zmian Strategii } \\
\text { rozwoju województwa } \\
\text { świętokrzyskiego do roku } \\
2020 \text { ) }\end{array}$ \\
\hline Kraków & $\begin{array}{l}\text { Krakowski Obszar Metro- } \\
\text { politalny }\end{array}$ & $\begin{array}{l}\text { jeden z obszarów Strategii } \\
\text { rozwoju województwa ma- } \\
\text { topolskiego na lata 2011- } \\
2020\end{array}$ & $\begin{array}{l}\text { monitoring za lata 2011- } \\
2013 \text { wykorzystujący } \\
\text { tylko dwa wskaźniki, } \\
\text { w Strategii rozwoju wo- } \\
\text { jewództwa matopolskie- } \\
\text { go dodatkowe wskaźniki } \\
\text { syntetyczne - w obu } \\
\text { przypadkach brak warto- } \\
\text { ści dla KOM }\end{array}$ \\
\hline Lublin & $\begin{array}{l}\text { Lubelski Obszar Metropo- } \\
\text { litalny }\end{array}$ & brak & $\begin{array}{l}\text { brak (odniesienie w stra- } \\
\text { tegii rozwoju wojewódz- } \\
\text { twa-brak wskaźników } \\
\text { monitoringu) }\end{array}$ \\
\hline
\end{tabular}

4 Por. definicję systemu monitorowania zawartą w pracy: Batóg, Batóg, Mojsiewicz, Wawrzy$\operatorname{niak}(2012$, s. 20). 


\begin{tabular}{|c|c|c|c|}
\hline 1 & 2 & 3 & 4 \\
\hline Łódź & $\begin{array}{l}\text { Łódzki Obszar Metro- } \\
\text { politalny }\end{array}$ & opracowana & $\begin{array}{l}\text { monitoring w strategii } \\
\text { ZIT opracowanej w ra- } \\
\text { mach Strategii rozwoju } \\
\text { Eódzkiego Obszaru Me- } \\
\text { tropolitalnego 2020+ }\end{array}$ \\
\hline Olsztyn & $\begin{array}{l}\text { Olsztyński Obszar Aglo- } \\
\text { meracyjny }\end{array}$ & opracowana & $\begin{array}{l}\text { brak (istnieją tylko wska- } \\
\text { źniki funkcji metropo- } \\
\text { litalnych w Strategii } \\
\text { rozwoju Miasta Olsztyn } \\
\text { 2020) }\end{array}$ \\
\hline Opole & Aglomeracja Opolska & opracowana & $\begin{array}{l}\text { opracowany (opis zakre- } \\
\text { su i zasad monitoringu, } \\
\text { wskaźniki tylko dla ce- } \\
\text { lów strategicznych) }\end{array}$ \\
\hline Poznań & Aglomeracja Poznańska & opracowana & brak \\
\hline Rzeszów & $\begin{array}{l}\text { Rzeszowski Obszar Metro- } \\
\text { politalny }\end{array}$ & $\begin{array}{l}\text { opracowana (tylko w za- } \\
\text { kresie zarządzania zmianą } \\
\text { gospodarczą) }\end{array}$ & opracowany \\
\hline Szczecin & $\begin{array}{l}\text { Szczeciński Obszar Metro- } \\
\text { politalny }\end{array}$ & opracowana & brak \\
\hline Warszawa & $\begin{array}{l}\text { Obszar Metropolitalny } \\
\text { Warszawy }\end{array}$ & $\begin{array}{l}\text { dla ZIT Warszawskiego } \\
\text { Obszaru Funkcjonalnego }\end{array}$ & brak \\
\hline Wrocław & Aglomeracja Wrocławska & $\begin{array}{l}\text { brak (istnieją dokumenty } \\
\text { stanowiące jej elementy) }\end{array}$ & $\begin{array}{l}\text { brak (tylko ogólny opis } \\
\text { monitoringu w Strategii } \\
\text { rozwoju województwa } \\
\text { dolnośląskiego) }\end{array}$ \\
\hline Zielona Góra & $\begin{array}{l}\text { Aglomeracja Zielonogór- } \\
\text { ska }\end{array}$ & brak & brak \\
\hline
\end{tabular}

Źródło: opracowanie własne na podstawie strategii rozwoju: obszarów metropolitalnych, miejskich obszarów funkcjonalnych, ZIT obszarów funkcjonalnych oraz województw.

Dwa MOF mają opracowane systemy monitoringu realizacji strategii rozwoju, dwa systemy stanowią elementy strategii rozwoju zintegrowanych inwestycji terytorialnych miejskich obszarów funkcjonalnych, a w jednym przypadku zarys systemu monitorowania jest częścią strategii rozwoju województwa. Oznacza to, że aż 12 MOF (71\%) nie ma rozwiązania tego typu (zob. tabela 1). Mamy więc do czynienia z sytuacją, w której większość miejskich obszarów funkcjonalnych nie jest w stanie sformułować oceny realizacji własnych strategii rozwoju. Konsekwencją braku procesu monitoringu może być też błędne postrzeganie efektów wdrażania strategii, które prowadzi do zaniechania niezbędnych korekt lub działań naprawczych elimi- 
nujących obszary problemowe w realizacji strategii (Raport monitoringowy... 2009, s. 13).

\section{Charakterystyka systemów i mierników monitorowania rozwoju MOF}

Poniżej zaprezentowano systemy monitorowania występujące w strategiach rozwoju wybranych obszarów metropolitalnych lub w innych dokumentach odnoszących się do tych strategii ${ }^{5}$.

\subsection{Kódzki Obszar Metropolitalny}

Podstawy systemu monitorowania realizacji strategii rozwoju Łódzkiego Obszaru Metropolitalnego (ŁOM) obejmujące właściwie wyłącznie wskaźniki monitorujące przedstawia strategia zintegrowanych inwestycji terytorialnych stanowiąca część operacyjną dokumentu Strategia rozwoju Lódzkiego Obszaru Metropolitalnego 2020+ (2014). Monitorowanie realizacji strategii ZIT ma przebiegać w dwóch ujęciach ${ }^{6}$. Monitorowane mają być rezultaty osiągane przez Łódzki Obszar Metropolitalny stanowiący integralną część województwa łódzkiego. Do tego poziomu monitorowania wykorzystane będą wskaźniki rezultatu zgodne z Regionalnym Programem Operacyjnym Województwa Łódzkiego na lata 2014-2020. Monitorowaniem objęte będą również rezultaty osiągane przez poszczególne gminy wchodzące w skład ŁOM. Wykaz wskaźników monitorujących rozwój ŁOM odpowiadających poszczególnym programom operacyjnym ZIT zaprezentowano w tabeli 2.

5 Systemy monitorowania przestrzeni miejskiej i obszarów zurbanizowanych spotykane w Europie i na świecie najczęściej dotyczą stanu i zmian środowiska naturalnego oraz zmian o charakterze przestrzennym - zob. np. Bagheri, Hjorth (2007); Zeng, Zhang, Cui, He (2015); Manzato, Rodrigues da Silva (2010). Jednym z wyjątków jest system monitorowania Clark County oparty na wskaźnikach ekonomicznych, społecznych, fiskalnych, ochrony zdrowia i bezpieczeństwa oraz środowiskowych (Sirgy, Phillips, Rahtz 2009, s. 51).

6 Dane statystyczne gromadzone w procesie monitorowania mogą być wykorzystane do: diagnozy sytuacji społeczno-gospodarczej, wyznaczenia celów i kierunków rozwoju oraz wsparcia w ramach polityki spójności (polityki miejskiej), analizowania zmian na obszarze funkcjonalnym, badania postępu realizacji wskaźników strategii, jak również do ewaluacji realizowanej polityki rozwoju MOF (Kamińska-Gawryluk 2014). 
Tabela 2. Wskaźniki monitorujące dla Łódzkiego Obszaru Metropolitalnego

\begin{tabular}{|c|c|}
\hline Program strategii ZIT & $\begin{array}{l}\text { Wskaźniki dla ŁOM - wskaźniki rezultatu RPO } \\
\text { (szacowane na poziomie województwa) }\end{array}$ \\
\hline $\begin{array}{l}\text { Kompleksowy Program Ochro- } \\
\text { ny Srodowiska i Efektywności } \\
\text { Energetycznej }\end{array}$ & $\begin{array}{ll}- & \text { udział produkcji energii elektrycznej ze źródeł odnawialnych } \\
& \text { w produkcji energii elektrycznej ogółem, } \\
- & \text { dodatkowa zdolność wytwarzania energii odnawialnej, } \\
- & \text { zmniejszenie zużycia energii pierwotnej w budynkach publicz- } \\
& \text { nych, } \\
- & \text { ilość zaoszczędzonej energii elektrycznej, } \\
- & \text { udział ludności korzystającej z komunalnych oczyszczalni } \\
& \text { ścieków w ludności ogółem }\end{array}$ \\
\hline $\begin{array}{l}\text { Kompleksowy Program Roz- } \\
\text { woju Kapitału Ludzkiego i Spo- } \\
\text { łecznego }\end{array}$ & 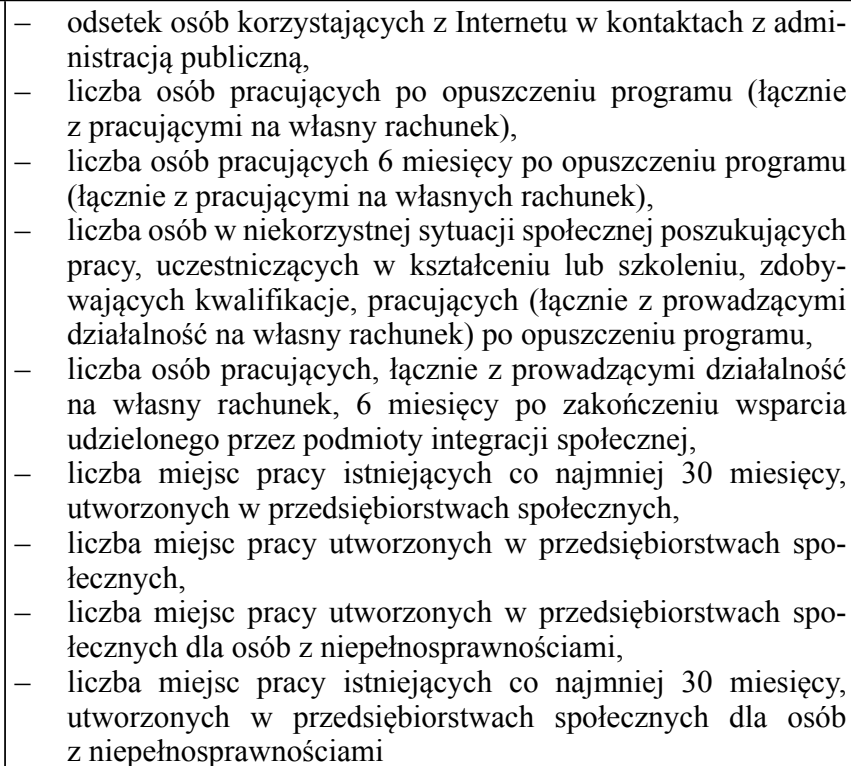 \\
\hline
\end{tabular}

Źródło: Strategia rozwoju Łódzkiego... (2014, s. 132-133).

\subsection{Rzeszowski Obszar Metropolitalny}

W Strategii zarzadzania zmiana gospodarcza dla Rzeszowskiego Obszaru Metropolitalnego na lata 2014-2020 (2014) określono płaszczyzny monitoringu dla powiatu rzeszowskiego, stwierdzając, że będzie on również dotyczył systematycznego obserwowania zmian występujących w ramach poszczególnych programów i celów strategii rozwoju Rzeszowskiego Obszaru Metropolitalnego (ROM). Określenie działań podejmowanych w ramach monitoringu uzupełniono o ustalenie 
procedur, ich ram czasowych oraz wykaz podmiotów realizujących poszczególne zadania $^{7}$. W tabeli 3 zamieszczono wskaźniki monitorowania, które mają stanowić podstawę oceny stopnia realizacji strategii rozwoju ROM w obszarze społecznym i gospodarczym.

Tabela 3. Wskaźniki monitorujące określone w strategii rozwoju Rzeszowskiego Obszaru Metropolitalnego

\begin{tabular}{|c|c|c|}
\hline Lp. & Nazwa miernika & Formuła/jednostka miary \\
\hline & 1 & 2 \\
\hline 1 & Przyrost naturalny na 1000 ludności & liczba urodzeń \\
\hline 2 & Wskaźnik obciążenia demograficznego & $\begin{array}{l}\text { stosunek liczby osób w wieku, gdy są one nie- } \\
\text { aktywne lub bierne zawodowo, do liczby osób } \\
\text { w wieku produkcyjnym }\end{array}$ \\
\hline 3 & Saldo migracji & $\begin{array}{l}\text { różnica między liczbą osób przyjeżdżających } \\
\text { i wyjeżdżających }\end{array}$ \\
\hline 4 & Wskaźnik wykształcenia & $\begin{array}{l}\text { struktura wykształcenia mieszkańców w wieku co } \\
\text { najmniej } 15 \text { lat }\end{array}$ \\
\hline 5 & $\begin{array}{l}\text { Kształcenie ustawiczne dorosłych lub osoby } \\
\text { dorosłe uczestniczące w kształceniu i szko- } \\
\text { leniu ogółem }\end{array}$ & $\begin{array}{l}\text { udział osób w wieku 25-64 lata uczących się i do- } \\
\text { kształcających się w ludności ogółem w tej samej } \\
\text { grupie wieku }\end{array}$ \\
\hline 6 & Wskaźnik edukacji przedszkolnej & $\begin{array}{l}\text { odsetek dzieci w wieku 3-5 lat objętych edukacja } \\
\text { przedszkolną }\end{array}$ \\
\hline 7 & $\begin{array}{l}\text { Rozwój kierunków kształcenia zgodnych } \\
\text { z potrzebami rynku }\end{array}$ & $\begin{array}{l}\text { liczba praktykantów szkół zawodowych i tech- } \\
\text { nicznych w przedsiębiorstwach Doliny Lotniczej }\end{array}$ \\
\hline 8 & Rozwój przedsiębiorczości w powiecie & $\begin{array}{l}\text { liczba przedsiębiorstw na } 10000 \text { mieszkańców } \\
\text { w powiecie }\end{array}$ \\
\hline 9 & Rozwój działalności badawczo-rozwojowej & $\begin{array}{l}\text { wydatki przedsiębiorstw na działalność badaw- } \\
\text { czo-rozwojową }\end{array}$ \\
\hline 10 & Poprawa jakości życia (ochrona zdrowia) & liczba mieszkańców na 1 łóżko szpitalne \\
\hline 11 & Poprawa jakości życia (ochrona zdrowia) & liczba mieszkańców na 1 lekarza \\
\hline 12 & Poprawa jakości życia (dostęp do kultury) & liczba ludności na 1 miejsce w kinach stałych \\
\hline 13 & Poprawa jakości życia (dostęp do kultury) & liczba ludności na 1 placówkę biblioteczną \\
\hline 14 & Poprawa jakości życia (dostęp do kultury) & $\begin{array}{l}\text { liczba woluminów w bibliotekach na } 1000 \text { miesz- } \\
\text { kańców }\end{array}$ \\
\hline 15 & Rozwój społeczeństwa obywatelskiego & wskaźnik frekwencji wyborczej \\
\hline 16 & Rozwój społeczeństwa obywatelskiego & $\begin{array}{l}\text { liczba aktywnych organizacji non-profit na } 1000 \\
\text { ludności }\end{array}$ \\
\hline 17 & $\begin{array}{l}\text { Poprawa jakości życia (ekonomiczny mier- } \\
\text { nik jakości życia) }\end{array}$ & przeciętne miesięczne wynagrodzenie \\
\hline 18 & $\begin{array}{l}\text { Poprawa jakości życia (współczynnik femi- } \\
\text { nizacji) }\end{array}$ & $\begin{array}{l}\text { liczba pracujących kobiet przypadająca na } 100 \\
\text { mężczyzn w grupie wiekowej 20-34 lata }\end{array}$ \\
\hline
\end{tabular}

7 Zob. również opracowanie Badanie społeczno-gospodarcze... (2013). 


\begin{tabular}{|c|c|c|}
\hline & 1 & 2 \\
\hline 19 & Rozwój gospodarczy (PKB per capita) & PKB na 1 mieszkańca \\
\hline 20 & $\begin{array}{l}\text { Rozwój gospodarczy (wskaźnik produktyw- } \\
\text { ności pracy) }\end{array}$ & wartość dodana brutto na 1 pracującego \\
\hline 21 & $\begin{array}{l}\text { Rozwój gospodarczy (struktura sektorowa } \\
\text { WDB) }\end{array}$ & $\begin{array}{l}\text { udział procentowy rolnictwa w całości regional- } \\
\text { nego PKB }\end{array}$ \\
\hline 22 & $\begin{array}{l}\text { Rozwój gospodarczy (wskaźnik przeżywal- } \\
\text { ności podmiotów gospodarczych) }\end{array}$ & $\begin{array}{l}\text { różnica między nowo zarejestrowanymi i wy- } \\
\text { rejestrowanymi podmiotami z rejestru REGON } \\
\text { na } 1000 \text { podmiotów }\end{array}$ \\
\hline 23 & $\begin{array}{l}\text { Rozwój gospodarczy (zatrudnienie według } \\
\text { działów PKD) }\end{array}$ & $\begin{array}{l}\text { udział procentowy rolnictwa w całości zatrudnie- } \\
\text { nia }\end{array}$ \\
\hline 24 & Wzrost zatrudnienia, nowe miejsca pracy & stopa bezrobocia \\
\hline 25 & Budowa gospodarki opartej na wiedzy & $\begin{array}{l}\text { nakłady na działalność innowacyjną - wartość } \\
\text { (w relacji do liczby przedsiębiorstw) w przedsię- } \\
\text { biorstwach przemysłowych }\end{array}$ \\
\hline 26 & $\begin{array}{l}\text { Budowa gospodarki opartej na wiedzy } \\
\text { (struktura PKB w układzie regionalnym) }\end{array}$ & $\begin{array}{l}\text { udział nakładów na działalność badawczo-roz- } \\
\text { wojową w PKB ogółem oraz ponoszonych przez } \\
\text { sektor przedsiębiorstw }\end{array}$ \\
\hline 27 & Budowa gospodarki opartej na wiedzy & liczba patentów na $1 \mathrm{mln}$ ludności \\
\hline 28 & Budowa gospodarki opartej na wiedzy & $\begin{array}{l}\text { liczba patentów zarejestrowanych w urzędzie pa- } \\
\text { tentowym }\end{array}$ \\
\hline 29 & $\begin{array}{l}\text { Budowa gospodarki opartej na wiedzy } \\
\text { (udział przedsiębiorstw wysokiej i średnio- } \\
\text { wysokiej techniki) }\end{array}$ & $\begin{array}{l}\text { udział przedsiębiorstw wysokiej i średniowyso- } \\
\text { kiej techniki w ogóle przedsiębiorstw (według } \\
\text { sekcji i działów PKD) }\end{array}$ \\
\hline 30 & $\begin{array}{l}\text { Budowa gospodarki opartej na wiedzy } \\
\text { (wskaźnik poziomu komercjalizacji inno- } \\
\text { wacji) }\end{array}$ & $\begin{array}{l}\text { udział przychodów netto ze sprzedaży produktów } \\
\text { innowacyjnych w przychodach netto ze sprzedaży } \\
\text { wyrobów ogółem }\end{array}$ \\
\hline 31 & $\begin{array}{l}\text { Budowa gospodarki opartej na wiedzy (kla- } \\
\text { stry gospodarcze) }\end{array}$ & $\begin{array}{l}\text { procent podmiotów deklarujących przynależnośćc } \\
\text { do klastrów (ewentualnie liczba zatrudnionych) }\end{array}$ \\
\hline
\end{tabular}

Źródło: Strategia zarządzania zmianą... (2014, s. 174-177).

Wydaje się, że niektóre z powyższych wskaźników nie będą mogły być obliczone dla miejskiego obszaru funkcjonalnego, ponieważ niektóre dostępne dane statystyki publicznej istnieją co najwyżej na poziomie podregionów. W jednym z nich widoczna jest sprzeczność między jego nazwą i formułą obliczeniową (wskaźnik nr 21).

\subsection{Opolski Obszar Metropolitalny}

W dokumencie Strategia rozwoju Aglomeracji Opolskiej na lata 2014 -2020 (2014) określono ramy monitorowania realizacji strategii rozwoju Aglome- 
racji Opolskiej. Obejmują one m.in. wskazanie podmiotu koordynującego prowadzenie monitoringu, ustalenie ram czasowych monitoringu oraz wykorzystywanych wskaźników. Monitoring ma być prowadzony na dwóch poziomach: celów strategicznych (według stopnia realizacji pakietu projektów określonych w ramach celów strategicznych podzielonych dodatkowo na cele szczegółowe) na podstawie zagregowanych wskaźników produktu i wskaźników rezultatu oraz projektów strategicznych na podstawie wskaźników produktu, analizy danych zastanych oraz informacji na temat realizacji rzeczowej i finansowej projektów strategicznych i komplementarnych. Poszczególnym celom szczegółowym przyporządkowano wskaźniki produktu (zob. tabela 4).

Tabela 4. Wskaźniki monitorujące określone w strategii rozwoju aglomeracji opolskiej

\begin{tabular}{|c|c|c|}
\hline Rodzaj celu & $\begin{array}{c}\text { Wskaźniki produktu } \\
\text { (dla celów szczegółowych) }\end{array}$ & $\begin{array}{c}\text { Wskaźniki rezultatu } \\
\text { (dla celu strategicznego) }\end{array}$ \\
\hline 1 & 2 & 3 \\
\hline \multicolumn{3}{|c|}{ Cel strategiczny I - Poprawa dostępności komunikacyjnej } \\
\hline $\begin{array}{l}\text { Cel szczegółowy I.1 - Zwiększanie } \\
\text { mobilności przez poprawę połączeń } \\
\text { wewnętrznego układu komunika- } \\
\text { cyjnego }\end{array}$ & $\begin{array}{l}\text { - } \text { całkowita długość nowych, prze- } \\
\text { budowanych lub zmodernizowa- } \\
\text { nych dróg, } \\
\text { - } \\
\text { liczba wybudowanych lub zmo- } \\
\text { dernizowanych obiektów inży- } \\
\text { nierskich (mostów, wiaduktów, } \\
\text { kładek, przepraw rzecznych) }\end{array}$ & $\begin{array}{l}\text { - } \text { całkowita długość dróg rowero- } \\
\text { wych na } 100 \mathrm{~km}^{2} \text {, } \\
\text { - } \text { liczba wypadków drogowych } \\
\text { z udziałem pieszych i rowerzy- } \\
\text { stów, } \\
\text { - łączna długość linii komunika- } \\
\text { cyjnych w publicznym transpor- } \\
\text { cie zbiorowym }\end{array}$ \\
\hline $\begin{array}{l}\text { Cel szczegółowy I. } 2 \text { - Rozwój ni- } \\
\text { skoemisyjnego transportu zbiorowe- } \\
\text { go i innych przyjaznych środowisku } \\
\text { form mobilności }\end{array}$ & $\begin{aligned} & \text { - } \text { liczba utworzonych/zorganizo- } \\
& \text { wanych miejsc parkingowych, } \\
& \text { - } \text { liczba wybudowanych obiektów } \\
& \text { park \& ride, } \\
& \text { - } \text { liczba wybudowanych obiektów } \\
& \text { bike \& ride, } \\
& \text { - } \text { liczba zainstalowanych inteligen- } \\
& \text { tnych systemów transportowych, } \\
&- \text { liczba wybudowanych, przebu- } \\
& \text { dowanych lub zmodernizowa- } \\
& \text { nych przystanków komunikacji } \\
& \text { publicznej, } \\
& \text { - } \text { liczba zakupionych jednostek } \\
& \text { taboru pasażerskiego w publicz- } \\
& \text { nym transporcie zbiorowym, } \\
& \text { - całkowita długość wybudowa- } \\
& \text { nych lub przebudowanych dróg } \\
& \text { rowerowych }\end{aligned}$ & \\
\hline
\end{tabular}




\begin{tabular}{|c|c|c|}
\hline 1 & 2 & 3 \\
\hline \multicolumn{3}{|c|}{ Cel strategiczny II - Rozwój gospodarczy } \\
\hline $\begin{array}{l}\text { Cel szczegółowy II.1 - Wzmocnie- } \\
\text { nie atrakcyjności oferty inwestycyj- } \\
\text { nej }\end{array}$ & $\begin{array}{l}\text { powierzchnia przygotowanych tere- } \\
\text { nów inwestycyjnych }\end{array}$ & \multirow{4}{*}{$\begin{array}{l}\text { - liczba miejsc pracy utworzonych } \\
\text { w przedsiębiorstwach zlokalizo- } \\
\text { wanych na przygotowanych tere- } \\
\text { nach, } \\
\text { - liczba inwestycji zlokalizowa- } \\
\text { nych na przygotowanych tere- } \\
\text { nach inwestycyjnych }\end{array}$} \\
\hline $\begin{array}{l}\text { Cel szczegółowy II.2 - Poprawa } \\
\text { konkurencyjności i innowacyjności } \\
\text { gospodarki }\end{array}$ & $\begin{aligned} & \text { - } \text { liczba wspartych IOB*, } \\
& \text { - } \text { liczba imprez o zasięgu ogólno- } \\
& \text { krajowym zrealizowana w Cen- } \\
& \text { trum Wystawienniczo-Kongreso- } \\
& \text { wym, } \\
& \text { - liczba przedsiębiorstw ulokowa- } \\
& \text { nych w parkach naukowo-tech- } \\
& \text { nologicznych } \\
&\end{aligned}$ & \\
\hline $\begin{array}{l}\text { Cel szczegółowy II.3 - Stworzenie } \\
\text { warunków do zwiększenia podaży } \\
\text { e-usług w sferze publicznej }\end{array}$ & $\begin{array}{l}\text { długość wybudowanej sieci szkiele- } \\
\text { towej lub dystrybucyjnej (w ramach } \\
\text { Optycznej Sieci Teleinformatycznej } \\
\text { Aglomeracji Opolskiej) }\end{array}$ & \\
\hline $\begin{array}{l}\text { Cel szczegółowy II.4 - Rozwój go- } \\
\text { spodarki opartej na zasobach kultu- } \\
\text { rowych i przyrodniczych }\end{array}$ & $\begin{array}{l}\text { - liczba zabytków nieruchomych } \\
\text { oraz obiektów dziedzictwa kul- } \\
\text { turowego objętych wsparciem, } \\
\text { - } \text { liczba opracowanych pakietów } \\
\text { turystycznych, } \\
\text { - } \text { długość utworzonych szlaków } \\
\text { turystycznych, } \\
\text { - długość przebudowanych szla- } \\
\text { ków turystycznych }\end{array}$ & \\
\hline \multicolumn{3}{|c|}{ Cel strategiczny III - Wysoka jakość edukacji } \\
\hline $\begin{array}{l}\text { Cel szczegółowy III.1 - Wsparcie } \\
\text { kształcenia ogólnego i zawodowego }\end{array}$ & $\begin{aligned} & \text { - } \text { liczba szkół i placówek systemu } \\
& \text { oświaty wyposażonych w sprzęt } \\
& \text { TIK** do prowadzenia zajęć edu- } \\
& \text { kacyjnych, } \\
& \text { - } \\
& \text { liczba szkół, których pracownie } \\
& \text { przedmiotowe doposażono, } \\
& \text { - } \\
& \text { liczba uczniów pochodzących } \\
& \text { z obszarów wiejskich objętych } \\
& \text { wsparciem, } \\
& \text { - liczba nauczycieli objętych } \\
& \text { wsparciem, } \\
& \text { - liczba uczniów objętych wspar- } \\
& \text { ciem }\end{aligned}$ & \multirow{2}{*}{$\begin{array}{l}\text { liczba szkół i placówek systemu } \\
\text { oświaty, które trwale wzmocniły } \\
\text { ofertę edukacyjną według zdiagno- } \\
\text { zowanych, indywidualnych potrzeb }\end{array}$} \\
\hline $\begin{array}{l}\text { Cel szczegółowy III.2 - Wsparcie } \\
\text { edukacji przedszkolnej }\end{array}$ & $\begin{array}{ll}\text { - } & \text { liczba dzieci objętych dodatko- } \\
\text { wymi zajęciami zwiększającymi } \\
\text { ich szanse edukacyjne w eduka- } \\
\text { cji przedszkolnej, } \\
\text { - } \\
\text { liczba nauczycieli objętych } \\
\text { wsparciem, } \\
\text { - } \\
\text { liczba uczniów z obszarów wiej- } \\
\text { skich objętych wsparciem }\end{array}$ & \\
\hline
\end{tabular}




\begin{tabular}{|c|c|c|}
\hline 1 & 2 & 3 \\
\hline \multicolumn{3}{|c|}{ Cel strategiczny IV - Ochrona środowiska } \\
\hline $\begin{array}{l}\text { Cel szczegółowy IV.1 - Ogranicze- } \\
\text { nie niskiej emisji przez zwiększenie } \\
\text { efektywności energetycznej }\end{array}$ & $\begin{array}{l}\text { - } \text { liczba zmodernizowanych ener- } \\
\text { getycznie budynków użyteczno- } \\
\text { ści publicznej, } \\
\text { - } \\
\text { liczba zainstalowanych lamp } \\
\text { o wysokiej efektywności energe- } \\
\text { tycznej }\end{array}$ & \multirow{2}{*}{\begin{tabular}{|l} 
spadek liczby zalań i podtopień \\
\\
\end{tabular}} \\
\hline $\begin{array}{l}\text { Cel szczegółowy IV. } 2 \text { - Zwiększe- } \\
\text { nie ochrony ludności i mienia przed } \\
\text { skutkami zagrożeń naturalnych }\end{array}$ & $\begin{array}{ll}\text { - } & \text { liczba przeszkolonych funkcjo- } \\
\text { nariuszy służb bezpieczeństwa } \\
\text { i strażaków, } \\
\text { - } \\
\text { liczba wybudowanych, rozbu- } \\
\text { dowanych i zmodernizowanych } \\
\text { urządzeń do celów ochrony } \\
\text { przeciwpowodziowej, } \\
\text { - } \text { liczba zintegrowanych systemów } \\
\text { koordynacji działań w sytuacji } \\
\text { wystąpienia nadzwyczajnych za- } \\
\text { grożeń }\end{array}$ & \\
\hline \multicolumn{3}{|c|}{ Cel strategiczny V - Rozwój obszarów wiejskich } \\
\hline $\begin{array}{l}\text { Cel szczegółowy V.1 - Wzmacnia- } \\
\text { nie funkcjonalności obszarów wiej- } \\
\text { skich przez rozwijanie i ulepszanie } \\
\text { infrastruktury sieciowej oraz popra- } \\
\text { wę jakości podstawowych usług lo- } \\
\text { kalnych świadczonych dla ludności } \\
\text { wiejskiej }\end{array}$ & $\begin{aligned} \text { - } & \text { długość wybudowanej sieci wo- } \\
& \text { dociągowej, } \\
- & \text { długość rozbudowanej, zmoder- } \\
& \text { nizowanej sieci wodociągowej, } \\
- & \text { długość wybudowanej kanaliza- } \\
& \text { cji sanitarnej, } \\
- & \text { długość rozbudowanej, zmoder- } \\
& \text { nizowanej kanalizacji sanitarnej }\end{aligned}$ & $\begin{array}{l}\text { - udział ludności korzystającej } \\
\text { z sieci wodociągowej w ludności } \\
\text { ogółem, } \\
\text { - udział ludności korzystającej } \\
\text { z sieci kanalizacyjnej w ludności } \\
\text { ogółem }\end{array}$ \\
\hline
\end{tabular}

${ }^{*}$ IOB - instytucje otoczenia biznesu; ${ }^{* *}$ TIK - technologie informacyjne i komunikacyjne.

Źródło: Strategia rozwoju Aglomeracji... (2014, s. 61-66).

\subsection{Krakowski Obszar Metropolitalny}

W przypadku Krakowskiego Obszaru Metropolitalnego i pozostałych subregionów województwa małopolskiego Raport z realizacji Strategii Rozwoju Województwa Małopolskiego 2011-2020 za okres 2011-2013 (2014) wskazał dwa wskaźniki osiągnięć: „Wartość inwestycji sektora prywatnego w przeliczeniu na mieszkańca województwa” oraz „Wyniki egzaminów na zakończenie szkoły podstawowej, testów gimnazjalnych i egzaminów maturalnych", które jednocześnie opatrzono ko- 
mentarzem, że aktualnie nie jest możliwe obliczenie wartości tych wskaźników dla tego obszaru. W Strategii Rozwoju Województwa Małopolskiego 2011-2020 (2011) oprócz powyższych wskaźników zaprezentowano również sześć wskaźników syntetycznych dla pięciu podregionów, mierzących: poziom rozwoju gospodarczego, dynamikę rozwoju gospodarczego, siłę rynku pracy, jakość kapitału ludzkiego, zmianę poziomu życia oraz zmianę poziomu usług publicznych. Niestety nie sformułowano odniesienia, czy przedstawione wskaźniki dotyczyć będą również Krakowskiego Obszaru Metropolitalnego.

Można zatem stwierdzić, że istniejące systemy monitorowania strategii rozwoju MOF charakteryzują się dużym zróżnicowaniem i w aktualnym kształcie nie mogą stanowić podstawy analizy porównawczej dokonywanej w skali kraju. Sytuację pogarsza brak takich systemów dla większości opracowanych strategii rozwoju miejskich obszarów funkcjonalnych ${ }^{8}$.

\section{Analiza zmian poziomu rozwoju gospodarczego MOF}

Badanie poziomu rozwoju gospodarczego MOF musi mieć nieco odmienny charakter od analizy tego zjawiska dla województw lub podregionów. Podstawową przyczyną jest fakt, że nie wszystkie mierniki, które są możliwe do wykorzystania na wyższych poziomach agregacji, mogą być zastosowane w przypadku MOF, ponieważ często ich elementami są powiaty, a także gminy. Dodatkowym utrudnieniem jest brak informacji statystycznej o wszystkich MOF opracowanych przez regionalne urzędy statystyczne9.

Dla 17 obszarów metropolitalnych w Polsce porównano stopień ich rozwoju gospodarczego w dwóch odrębnych latach - 2010 oraz 2013. Wykorzystano w tym celu taksonomiczną miarę rozwoju (TMR) wprowadzoną przez Z. Hellwiga (Hellwig

8 Obserwowana jest tendencja umieszczania systemów monitorowania MOF w strategiach ZIT - przykładem może być zaawansowany system monitorowania zawarty w projekcie strategii ZIT Białostockiego Obszaru Funkcjonalnego na lata 2014-2020, http://bof.org.pl/dok/Projekt\%20Strategii _ZIT_BOF_21_07_2014.pdf(20.04.2015).

9 Potwierdzają to liczne wskazania w dokumentach dotyczących rozwoju poszczególnych regionów - np. „Krakowski Obszar Metropolitalny ma zdecydowanie odmienny od pozostałych charakter. Obszar ten został opisany w dużej mierze nieadekwatnymi wskaźnikami. Względnie trudne jest też prowadzenie analizy porównawczej KOM z innymi obszarami metropolitalnymi, z uwagi na brak danych porównawczych" (Raport monitoringowy... 2009, s. 106). Zob. również: Kamińska-Gawryluk (2014, s. 28-31). 
$1968)^{10}$. Podstawą obliczeń były trzy zmienne: wskaźnik bezrobocia, liczba podmiotów gospodarki narodowej na 1000 osób oraz dochody jednostek samorządowych na 1 mieszkańca. Wybór tych zmiennych był podyktowany możliwością porównywania ich między obszarami (wielkości względne - wskaźniki natężenia), jak również dostępnością danych statystycznych na poziomie gmin.

Na rysunku 1 przedstawiono wartości taksonomicznej miary rozwoju dla 17 obszarów metropolitalnych w Polsce w 2010 oraz 2013 r.

Rysunek 1. Taksonomiczna miara rozwoju obszarów metropolitalnych w 2010 i 2013 r.

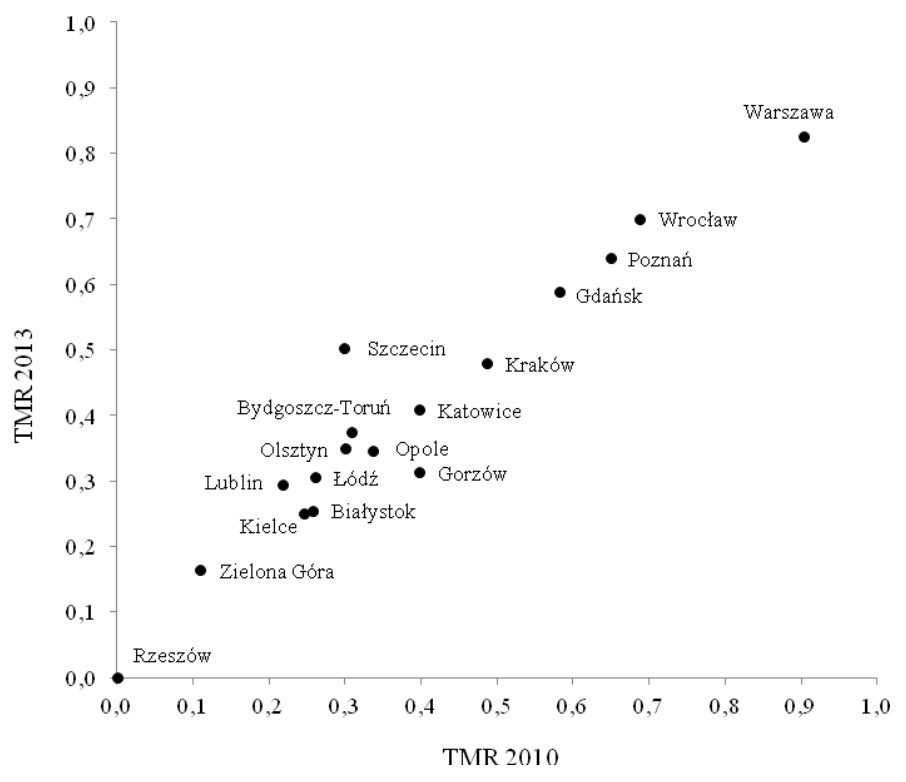

Źródło: obliczenia własne na podstawie danych GUS.

Większość punktów reprezentujących poszczególne obszary metropolitalne układa się wzdłuż osi symetrii układu współrzędnych. Te same miejsca w rankingu w 2013 r. co w 2010 r. zachowały cztery najlepsze obszary metropolitalne: warszawski, wrocławski, poznański oraz gdański, słaby obszar łódzki, a także dwa najgorsze

10 Na potrzeby przeprowadzonej analizy zmodyfikowano sposób normalizacji zmiennych, wykorzystując metodę unitaryzacji zerowanej, czego konsekwencją była również normalizacja odległości na przedział $\langle 0,1\rangle$ z wykorzystaniem maksymalnej wartości odległości indywidualnej - por. Batóg (2014). 
obszary - rzeszowski i zielonogórski. Nieznaczne przesunięcia w rankingu (jedno miejsce w górę lub w dół) odnotowały obszary metropolitalne: kielecki, białostocki, olsztyński, bydgosko-toruński, katowicki oraz krakowski. O dwa miejsca w górę rankingu przesunął się Obszar Metropolitalny Lubelski, a o dwa miejsca pogorszył swoją pozycję obszar opolski. Największy spadek, o cztery miejsca, wystąpił dla obszaru gorzowskiego, a największy wzrost, aż o sześć miejsc, dla Szczecińskiego Obszaru Metropolitalnego. Warto jednocześnie zwrócić uwagę, że kolejność poszczególnych MOF jest w bardzo dużym stopniu zgodna z miejscami, jakie zajmują w wielu rankingach województwa, w których one występują.

\section{Podsumowanie}

W literaturze spotyka się pogląd, że metropolie w warunkach gospodarki opartej na wiedzy są silniej powiązane między sobą niż ze swoimi obszarami funkcjonalnymi, co może powodować występowanie znaczących dysproporcji w poziomie rozwoju społeczno-gospodarczego między obszarem metropolitalnym (często samym miastem centralnym) a jego otoczeniem regionalnym. W rezultacie rozprzestrzenianie się efektów rozwoju z metropolii w kierunku otaczającego ją regionu jest słabe i ma ograniczony zasięg (Jałowiecki 2007; Smętowski 2007; Heffner 2010). Mając jednak na uwadze zachodzące na świecie procesy urbanizacji, wydaje się, że rola obszarów miejskich będzie z każdym rokiem rosła. Rozwój miast i obszarów z nimi powiązanych terytorialnie i funkcyjnie decydować będzie o poziomie rozwoju całego $\mathrm{kraju}^{11}$. Z tego powodu tak ważne jest prowadzenie analiz pozwalających ocenić stopień przygotowania miejskich obszarów funkcjonalnych do pełnienia przypisanych im funkcji. Istotnym czynnikiem w tym zakresie jest istnienie strategii rozwoju poszczególnych MOF oraz sprawnych systemów ich monitorowania i oceny. Badanie tych dwóch elementów dla polskich MOF wskazało na znaczące braki w tym zakresie.

Ważnym zadaniem, oprócz uzupełniania luki w zakresie opracowywania strategii rozwoju i systemów monitorowania MOF, jest również ujednolicenie systemów monitorowania miejskich obszarów funkcjonalnych ${ }^{12}$. Pewien krok w tym zakresie

11 Zob. pracę: Wplyw potencjatu... (2013).

12 Na niski poziom rozwoju obszarów miejskich, brak porównywalności międzynarodowej danych statystycznych dotyczących tych obszarów oraz konieczność gromadzenia danych nie według 
stanowią opracowywane przez regionalne urzędy statystyczne publikacje o MOF w ramach statystycznego vademecum samorządowca. Niestety nie są one przygotowywane przez wszystkie regionalne urzędy statystyczne i nie charakteryzują się tym samym zakresem danych. Innym źródłem porównywalnych danych mogą być projekty lub badania prowadzone przez GUS. Ich przykładem może być działanie pt. „Opracowanie wskaźników monitorowania miejskich obszarów funkcjonalnych ośrodków wojewódzkich w zakresie rozwoju budownictwa mieszkaniowego, na poziomie NTS 5 (gminy)", którego celem jest stworzenie metodyki pozyskiwania danych i obliczania wskaźników służących monitorowaniu zmian zachodzących w miejskich obszarach funkcjonalnych ośrodków wojewódzkich w zakresie rozwoju budownictwa mieszkaniowego na tle ich sytuacji demograficznej i społeczno-gospodarczej. Wydaje się, że znaczącą rolę w tym zakresie może również odegrać Ministerstwo Rozwoju Regionalnego oraz zintegrowane inwestycje terytorialne, które zgodnie z zapisami rozporządzeń regulujących Politykę Spójności Unii Europejskiej oraz z uzgodnieniami zawartymi w polskiej Umowie Partnerstwa, przyjętej przez Rząd RP 8 stycznia 2014 r., są najistotniejszym narzędziem wsparcia miast i ich obszarów funkcjonalnych w latach 2014-2020. ZIT będą realizowane przede wszystkim na terenie miast wojewódzkich i ich obszarów funkcjonalnych w ramach regionalnych programów operacyjnych, które na ten cel otrzymały dodatkową pulę środków z rezerwy programowej.

Analiza poziomu rozwoju gospodarczego obszarów metropolitalnych pozwoliła zauważyć stosunkowo wysokie podobieństwo ich rankingów uzyskanych dla dwóch lat - 2010 i 2013. Tylko dwa obszary: gorzowski i szczeciński, charakteryzowały się znaczącą zmianą pozycji, odpowiednio negatywną i pozytywną. Oceniając wyniki tej analizy, należy jednak pamiętać, że uzyskano je na podstawie trzech wskaźników i obejmowały one okres czteroletni.

kryteriów administracyjnych, lecz pełnionych przez nie funkcji ekonomicznych, zwracają uwagę autorzy pracy: Redefining ,Urban”... (2012). 


\section{Literatura}

Badanie spoleczno-gospodarcze w ramach projektu pt. PROM - Partnerstwa na rzecz Rzeszowskiego Obszaru Metropolitalnego - powiat rzeszowski. Raport październik 2013 (2013), RARR SA, Rzeszów.

Bagheri A., Hjorth P. (2007), A Framework for Process Indicators to Monitor for Sustainable Development: Practice to an Urban Water System, „Environment, Development and Sustainability", vol. 9, nr 2, s. 143-161.

Batóg J. (2014), Obszary problemowe w województwie zachodniopomorskim - analiza zmian w czasie, w: Modelowanie i prognozowanie zjawisk spoleczno-gospodarczych. Teoria i praktyka, red. B. Pawełek, Wydawnictwo Uniwersytetu Ekonomicznego w Krakowie, Kraków.

Batóg B., Batóg J., Mojsiewicz M., Wawrzyniak K. (2012), Statystyczny system oceny stopnia realizacji strategii rozwoju, „Wiadomości Statystyczne”, nr 12, s. 20-35.

Sirgy M.J., Phillips R., Rahtz D.R. (red.) (2009), Community Quality-of-Life Indicators: Best Cases III, Springer Netherlands, Dordrecht.

Heffner K. (2010), Regiony międzymetropolitalne a efekty polityki spójności w Polsce, w: Jaka polityka spójności po roku 2013?, red. M. Klamut, E. Szostak, Wydawnictwo Uniwersytetu Ekonomicznego we Wrocławiu, Wrocław, s. 163-184.

Hellwig Z. (1968), Zastosowanie metody taksonomicznej do typologicznego podziału krajów ze względu na poziom ich rozwoju oraz zasoby i strukture wykwalifikowanych kadr, „Przegląd Statystyczny”, nr 4, s. 307-327.

Jałowiecki B. (2007), Globalny świat metropolii, EUROREG, Wydawnictwo Naukowe Scholar, Warszawa.

Koncepcja Przestrzennego Zagospodarowania Kraju 2030, załącznik do uchwały nr 239 Rady Ministrów z dnia 13 grudnia 2011 r., „Monitor Polski” z 27 kwietnia 2012, poz. 252, s. 17.

Kryteria delimitacji miejskich obszarów funkcjonalnych ośrodków wojewódzkich (2013), Ministerstwo Rozwoju Regionalnego, Warszawa.

Manzato G.G., Rodrigues da Silva A.N. (2010), Spatial-Temporal Combination of Variables for Monitoring Changes in Metropolitan Areas, „Applied Spatial Analysis and Policy”, vol. 3, nr 1, s. 25-44.

Kamińska-Gawryluk E. (2014), Miejskie obszary funkcjonalne jako odbiorcy danych statystycznych w latach 2014-2020, Urząd Statystyczny w Białymstoku, http://lublin. stat.gov.pl/gfx/lublin/userfiles/public/konferencje_i_seminaria/statystyka_w_procesie_monitorowa/e_kaminska_gawryluk.pdf (31.07.2015). 
Raport monitoringowy z realizacji Strategii Rozwoju Województwa Matopolskiego w latach 2007-2008 (2009), Zarząd Województwa Małopolskiego, Kraków.

Raport z realizacji Strategii Rozwoju Województwa Małopolskiego 2011-2020 za okres

2011-2013 (2014), Urząd Marszałkowski Województwa Małopolskiego, Departament

Polityki Regionalnej, Małopolskie Obserwatorium Rozwoju Regionalnego, Kraków.

Redefining "Urban": A New Way to Measure Metropolitan Areas (2012), OECD.

Smętowski M. (2007), Nowe relacje metropolia - region $w$ gospodarce informacyjnej na przykładzie Warszawy i Mazowsza, w: Polska regionalna i lokalna w świetle badań

EUROREG-u, red. G. Gorzelak, Wydawnictwo Naukowe Scholar, Warszawa, s. $163-188$.

Strategia rozwoju Aglomeracji Opolskiej na lata 2014-2020 (2014), Lider Projekt, Opole.

Strategia rozwoju Lódzkiego Obszaru Metropolitalnego 2020+, część II: Strategia rozwoju (2014), PTE Oddział w Łodzi, Łódź.

Strategia Rozwoju Województwa Małopolskiego 2011-2020 (2011), Urząd Marszałkowski

Województwa Małopolskiego, Departament Polityki Regionalnej, Kraków.

Strategia zarzadzania zmiana gospodarcza dla Rzeszowskiego Obszaru Metropolitalnego na lata 2014-2020 (2014), Partnerstwa na rzecz Rzeszowskiego Obszaru Metropolitalnego, RARR SA w Rzeszowie, Rzeszów.

Wplyw potencjalu demograficznego i gospodarczego miast wojewódzkich na kondycje województw (2013), Mazowiecki Ośrodek Badań Regionalnych, Warszawa.

Zeng Ch., Zhang M., Cui J., He S. (2015), Monitoring and Modeling Urban ExpansionA Spatially Explicit and Multi-Scale Perspective, „Cities - The International Journal of Urban Policy and Planning”, vol. 43, s. 92-103.

\title{
MONITORING OF DEVELOPMENT STRATEGIES IN THE LIGHT OF DELIMITATION OF URBAN FUNCTIONAL AREAS
}

\begin{abstract}
Presented analysis indicates that freshly defined metropolitan areas in Poland begin to create the development strategies and systems of monitoring and evaluation of their strategic and other goals. These documents have different level of advancement. The review of existing development strategies in Poland and in Europe allows to formulate the conclusion that statistical data are crucial for realization of monitoring and evaluation of development strate-
\end{abstract}


gies. The statistical data should include information on natural environment, transportation, demography, state property, health and knowledge-based economy. There is also need for general set of indices that enables the regional, national and international comparisons. The comparison of the economic situation of Polish functional areas in 2010 and 2013 was also carried out. The rankings of these areas were very similar to rankings of Polish voivodships.

Translated by Barbara Batóg

Keywords: functional areas, metropolitan areas, monitoring

JEL Code: R51 